\title{
The Poor \\ in \\ ASEAN Cities
}


The Institute of Southeast Asian Studies was established as an autonomous organization in 1968. It is a regional research centre for scholars and other specialists concerned with modern Southeast Asia, particularly the multi-faceted problems of stability and security, economic development, and political and social change.

The Institute is governed by a twenty-two-member Board of Trustees comprising nominees from the Singapore Government, the National University of Singapore, the various Chambers of Commerce, and professional and civic organizations. A ten-man Executive Committee oversees day-to-day operations; it is chaired by the Director, the Institute's chief academic and administrative officer.

The Social Issues in Southeast Asia (SISEA) programme was established at the Institute in 1986. It addresses itself to the study of the nature and dynamics of ethnicity, religions, urbanism, and population change in Southeast Asia. These issues are examined with particular attention to the implications for, and relevance to, an understanding of problems of development and of societal conflict and co-operation. SISEA is guided by a Regional Advisory Board comprising senior scholars from the various Southeast Asian countries. At the Institute, SISEA comes under the overall charge of the Director while its day-to-day running is the responsibility of the Co-ordinator. 


\section{The Poor}

in

\section{ASEANCities}

\section{Perspectives in Health Care Management}

Compiled by

Trinidad S. Osteria 


\author{
Published by \\ Institute of Southeast Asian Studies \\ Heng Mui Keng Terrace \\ Pasir Panjang \\ Singapore 0511
}

All rights reserved.

No part of this publication may be reproduced, stored in a retrieval system, or transmitted in any form or by any means, electronic, mechanical, photocopying, recording or otherwise, without the prior permission of the Institute of Southeast Asian Studies.

(C) 1991 Institute of Southeast Asian Studies

\title{
Cataloguing in Publication Data
}

Osteria, Trinidad S.

The poor in ASEAN cities: perspectives in health care management.

1. Urban poor - Medical care - ASEAN countries.

2. Urban health - ASEAN countries.

3. Poor - Medical care - ASEAN countries.

4. Medical care - ASEAN countries.

I. Title.

HV4141 A5085 $1991 \quad$ sls91-70079

ISBN 981-3035-76-5 (soft cover)

ISBN 981-3035-84-6 (hard cover)

The responsibility for facts and opinions expressed in this publication rests exclusively with the compiler and her interpretations do not necessarily reflect the views or the policy of the Institute or its supporters.

Typeset by International Typesetters

Printed in Singapore by Kin Keong Printing Co. Pte. Ltd. 